\title{
Impact of different emission inventories on simulated tropospheric ozone over China: a regional chemical transport model evaluation
}

\author{
J. $\mathrm{Ma}^{1}$ and J. A. van Aardenne ${ }^{2}$ \\ ${ }^{1}$ Chinese Academy of Meteorological Sciences, People's Republic of China \\ ${ }^{2}$ Max Planck Institute for Chemistry, Mainz, Germany \\ Received: 7 November 2003 - Published in Atmos. Chem. Phys. Discuss.: 22 January 2004 \\ Revised: 17 May 2004 - Accepted: 24 May 2004 - Published: 21 June 2004
}

\begin{abstract}
The importance of emission inventory uncertainty on the simulation of summertime tropospheric ozone over China has been analyzed using a regional chemical transport model. Three independent emissions inventories, that are (i) emission estimates from the Emission Database for Global Atmospheric Research (EDGAR) for the year 1995, (ii) a regional emission inventory used in the Transport and Chemical Evolution over the Pacific (TRACE-P) program with emissions for the year 2000 and (iii) a national emission inventory used in the China Ozone Research Program (CORP) with emission estimates for the year 1995, are used for model simulation over a summer period. Methods used for the development of the inventories are discussed and differences in simulated ozone and its precursors with these emission inventories are analyzed. Comparison of the emission inventories revealed large differences in the emission estimates (up to $50 \%$ for $\mathrm{NO}_{\mathrm{x}}, \sim 100 \%$ for NMVOC and $\sim 1000 \%$ for CO). Application of the different emission inventories in three model simulations showed minor differences in both surface $\mathrm{O}_{3}$ in rather unpolluted areas in China and at higher altitudes (500 mbar). In polluted areas, differences in surface $\mathrm{O}_{3}$ are $30-50 \%$ between the different model simulations which seem rather small taking into account the large differences in the emission inventories. Additional sensitivity runs showed that the difference in $\mathrm{NO}_{\mathrm{x}}$ emissions as well NMVOC emissions is a dominant factor which controls the differences in simulated $\mathrm{O}_{3}$ concentrations while the impact of differences in $\mathrm{CO}$ emissions is relatively small. Although the $\mathrm{CO}$ emission estimate by CORP seems to be underestimated, there is no confidence to highlight one emission inventory better than the others.
\end{abstract}

Correspondence to: J. A. van Aardenne

(aardenne@mpch-mainz.mpg.de)

\section{Introduction}

Emission inventories are applied both in policymaking and in scientific research, therefore a variety of emission inventories exist, each with different characteristics (Pacyna and Graedel, 1995). Since it is impossible to measure each individual emission source on the scale of a country or region, large-scale emission inventories are constructed using an emission factor approach. As a result, emissions inventories are inaccurate representations of the emission that has actually occurred. For Asian emission inventories, this inaccuracy could be large because measurement data on emission factors are often not available resulting in application of emission factors from European or North American studies (e.g. Van Aardenne et al., 1999).

In the past decades, photochemical air quality models have evolved greatly with advancements, in not only the description of physical and chemical processes, but also the computational implementation, including numerical methods. The lack of knowledge on the accuracy of emission inventories, i.e. emission inventory uncertainty, appears to be a major limitation in the current ability to predict the dynamics of ozone, as well as the impact of control strategies (Russel and Dennis, 2000). Although modelling studies often claim that assessment of the emission inventory uncertainty is important, it is often not addressed to what extent uncertainty in the emission inventories really matter for the outcome of atmospheric modelling studies. This is a dilemma that often arises in discussion between modellers and the emission inventory community. In order to pinpoint the emission inventory as cause for the difference between model calculations and observations, quantitative information is needed on how much the emission inventory is an inaccurate calculation of the 'real' emission. Although most of the processes leading to emissions are understood, data on these processes (activity data or emission factors) are often not available in the amount of detail required for accurate emission inventory 
Table 1. Chinese emissions of $\mathrm{NO}_{\mathrm{x}}, \mathrm{CO}$ and $\mathrm{NMVOC}$ as presented in the three independent emission inventory studies.

\begin{tabular}{lccccccccc}
\hline & \multicolumn{3}{c}{$\mathrm{NO}_{\mathrm{x}}\left(\mathrm{Tg} \mathrm{NO}_{2} \mathrm{yr}^{-1}\right)$} & \multicolumn{2}{c}{$\mathrm{CO}\left(\mathrm{Tg} \mathrm{CO} \mathrm{yr}^{-1}\right)$} & \multicolumn{3}{c}{$\mathrm{NMVOC}\left(\mathrm{Tg} \mathrm{yr}^{-1}\right)$} \\
\cline { 2 - 10 } & EDG & TRA & $\mathrm{COR}$ & EDG & TRA & COR & EDG & TRA & COR \\
\hline Industry & 4.8 & 2.8 & & 7.6 & $18.0^{\mathrm{a})}$ & & 1.6 & 3.7 & \\
Domestic & 1.8 & 0.7 & & 66.3 & 44.0 & & 6.3 & 5.6 & \\
Transport & 1.5 & 2.6 & & 13.5 & 38.0 & & 1.7 & 5.3 & \\
Power generation & 3.9 & 4.4 & & 0.3 & & & 1.2 & 0.1 & \\
Biomass burning & 0.02 & 0.8 & & 0.4 & 15.7 & & 0.03 & 2.7 & \\
Other & 0.01 & & & 0.3 & & & 0.2 & & \\
Total & 12.2 & 11.3 & 18.8 & 88.4 & 115.7 & 10.0 & 11.1 & 17.4 & $24.8^{\mathrm{b})}$ \\
\hline
\end{tabular}

Sources: Olivier et al. (2002) for EDGAR data (EDG), Streets et al. (2003) for TRACE-P data (TRA) and Bai (1996) for CORP data (COR). Sectional information for CORP is not available. ${ }^{\text {a) }}$ Industry contains power generation emissions. ${ }^{\text {b) }}$ NMVOC emissions have been estimated by using a $\mathrm{NO}_{\mathrm{x}}-\mathrm{NMVOC}$ scaling factor.

construction. Gathering of these data is a time consuming task and in order to decide how much effort should be spent on the construction of an inventory, insight in the extent to which an inventory should be accurate is needed.

In this paper, results are presented of an analysis, which tests the sensitivity of a regional chemical transport model (Ma et al., 2002a) used to calculate summertime tropospheric ozone over China to the uncertainty in the anthropogenic emission estimates of $\mathrm{NO}_{\mathrm{x}}, \mathrm{CO}$ and NMVOC. The principle of this sensitivity run is that three independent emission inventories for China are used while keeping all other model settings (including non-Chinese emissions) constant.

\section{Anthropogenic emission inventories}

The used emission inventories are (i) emission estimates for the year 1995 from the Emission Database for Global Atmospheric Research (EDGAR v32; Olivier et al., 1999, 2002), (ii) regional emission inventory used in the Transport and Chemical Evolution over the Pacific (TRACE-P) program with emission estimates for the year 2000 (Streets et al., 2003) and (iii) national emission inventory used in the Chinese Ozone Research Programme (CORP) with emission estimates for the year 1995 (Bai, 1996).

The inventories are different in (i) year for which emissions are calculated, (ii) level of detail that is included, (iii) information source for emission factors and activity data, and (iv) method of distributing emissions to $\left(1^{\circ} \times 1^{\circ}\right)$ grid cells. The inventories share an important issue: due to the nature of emission factor calculations all inventories are known to be inaccurate representations of the emissions that have taken place in China over the year 1995. The extent to which the inventories are inaccurate is unknown. Furthermore, it is not assessed which inventory is the most accurate one.

\subsection{The EDGAR v3 emission inventory}

The EDGAR database presents a global estimate of several compounds including $\mathrm{NO}_{\mathrm{x}}, \mathrm{CO}$, and $\mathrm{NMVOC}$ for the year 1990 and 1995 (Olivier et al., 1999, 2002). Emissions are calculated using an emission factor approach and emissions by sector are distributed on a $1^{\circ} \times 1^{\circ}$ grid based mainly on population maps.

The methodology of EDGAR is described in detail in (Olivier et al., 1996, 1999, 2002). Activity data by country - and thus for China - were taken from datasets compiled by international organizations which have performed consistency checks on the data. For example, energy data have been taken from the "Energy Statistics of OECD and non-OECD countries" (IEA/OECD, 1997) and industrial production data from "Industrial Commodity Production Statistics database" (UN, 1998). Applied emission factors are a mixture of emission factors for groups of individual countries based on national or regional studies and global default emission factors when no specific information was available. For China, most emission factors for $\mathrm{NO}_{\mathrm{x}}, \mathrm{CO}$ and $\mathrm{NMVOC}$ are global or regional default factors taken from the literature (Olivier et al., 2002 and references therein). Examples of country specific factors are those for $\mathrm{CO}$ and $\mathrm{NO}_{\mathrm{x}}$ from coalmine fires.

\subsection{The TRACE-P emission inventory}

As input for the TRACE-P project, Streets et al. (2003) have constructed a regional emission inventory for Asia with annual total emissions by country representing emission estimates for the year 2000. Emissions of several compounds, including $\mathrm{NO}_{\mathrm{x}}, \mathrm{CO}$ and $\mathrm{NMVOC}$ are calculated on the country level. Chinese emissions are calculated by province. Emissions of NMVOC are further specified into 6 categories.

The data used consist of actual statistical data for the year 2000, model forecasts values based on 1995 values and trend extrapolations from emission estimates for the late 1990's. For China, activity data have been taken from 

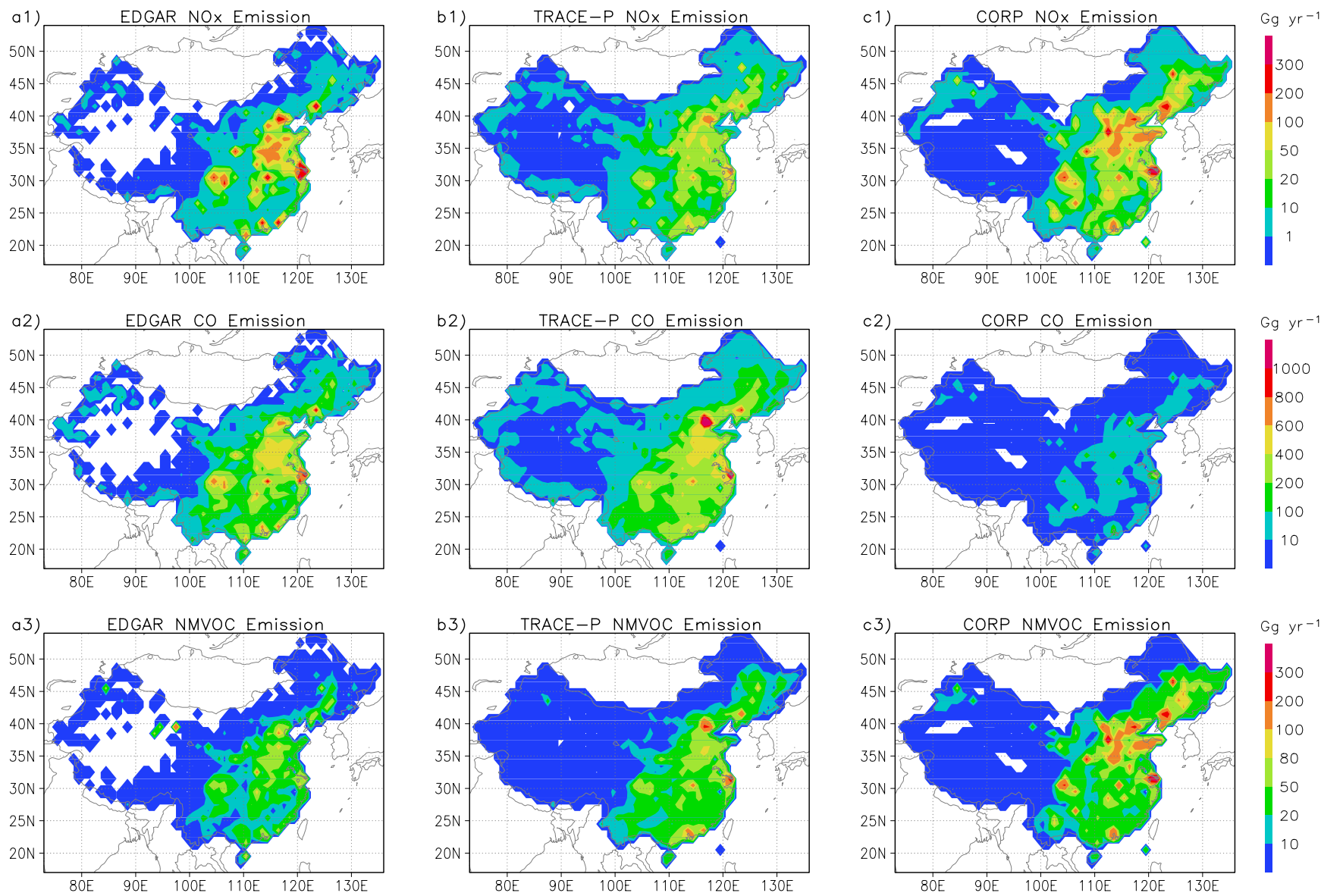

Fig. 1. Anthropogenic surface emissions of $\mathrm{NO}_{\mathrm{x}}, \mathrm{CO}$, NMVOC over China according to the EDGAR, TRACE-P and CORP estimates. Both EDGAR and CORP estimates are for the year of 1995, and TRACE-P is for the year of 2000. While EDGAR and TRACE-P NMVOC emissions are independent on $\mathrm{NO}_{\mathrm{x}}$ emissions, CORP NMVOC emissions are scaled to $\mathrm{NO}_{\mathrm{x}}$ emissions. Units are $\mathrm{Gg} \mathrm{yr}^{-1}$ per $1^{\circ} \times 1^{\circ}$ grid.

country specific studies. For example, fuel use by sector and province were taken from by Sinton and Fridley (2000). Emission factors were applied both from studies on China (e.g. vehicle emission factors from Fu et al., 2001) and from global studies (e.g. biomass burning factors from Andreae and Merlet, 2001). Emissions by sector are distributed on $1^{\circ} \times 1^{\circ}$ grid cells based on population maps but also on for example road network maps.

\subsection{The CORP emission inventory}

For the CORP programme, Bai (1996) has calculated an emission inventory for China with NOx emissions representative for the year 1992. This inventory has been updated for the year 1995 with CO emissions added. Unfortunately, this update has not been published. NMVOC emissions were not included in the CORP emission inventory. For modelling purposes, Ma et al. (2002a) added NMVOC emissions using a $\mathrm{NO}_{\mathrm{x}} / \mathrm{NMVOC}$ factor based on Berntsen et al. (1996). These NMVOC emissions of Ma et al. (2002a) are used for the inventory. The $\mathrm{NO}_{\mathrm{x}}$ emissions have been calculated based on emission factors measured in China (Bai, 1996). For CO emissions, the source of information is unknown. Activity data have been taken from a variety of information sources on either State, Province and city level (Bai, 1996 and references therein). In general, energy statistics were available on at least the province level and for one fourth of the provinces data was available on the prefecture level. Activity data on industrial processes was taken from Ministerial yearbook publications. The calculated emissions were distributed on a $1^{\circ} \times 1^{\circ}$ grid by dividing emissions by prefecture area. For grid boxes that contain more than one prefecture, the emission in the grid is averaged using weighted emission values.

\subsection{Differences between emission inventories}

Table 1 presents a summary of the emission estimates for Chinese $\mathrm{NO}_{\mathrm{x}}, \mathrm{CO}$ and NMVOC with Fig. 1 presenting the emission on grid. As shown in Table 1, the $\mathrm{NO}_{\mathrm{x}}$ emissions 

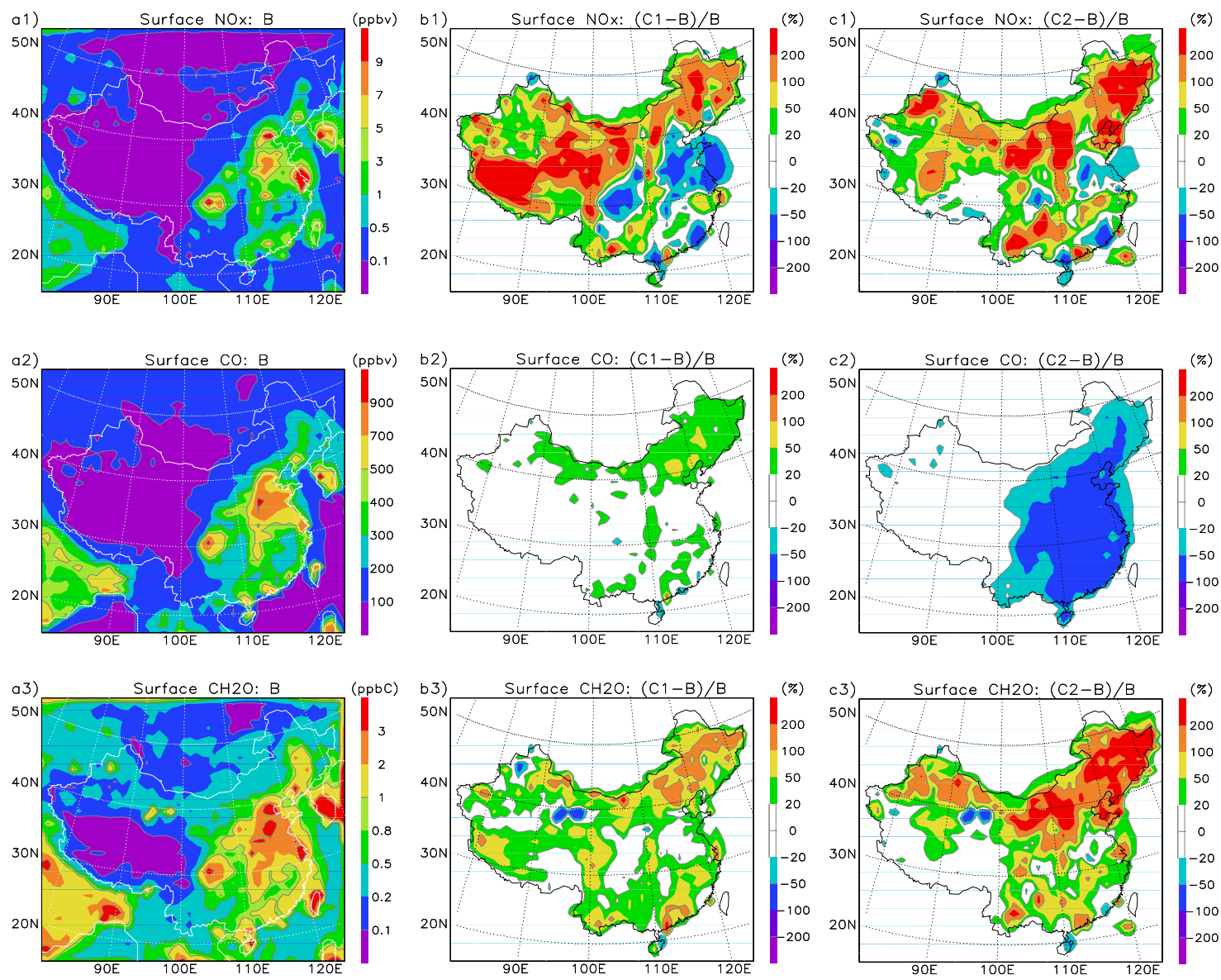

Fig. 2. Difference in surface $\mathrm{NO}_{\mathrm{x}}, \mathrm{CO}$ and $\mathrm{CH}_{2} \mathrm{O}$ due to the use of different emission inventories EDGAR, TRACE-P and CORP (denoted as cases B, C1 and C2, respectively). Simulated results with EDGAR are given as reference and the differences are shown with the relative deviations of TRACE-P and CORP to EDGAR. Note that the relative differences are large for $\mathrm{NO}_{\mathrm{x}}$ in western China due to low emissions and concentrations of $\mathrm{NO}_{\mathrm{X}}$ in unpolluted areas.

range from $11 \mathrm{Tg}$ (TRACE-P) to $19 \mathrm{Tg}$ (CORP) with the CORP inventory being about $50-60 \%$ higher than both the EDGAR and TRACE-P work. Although the EDGAR and TRACE-P $\mathrm{NO}_{\mathrm{x}}$ budget are comparable $(\sim 10 \%)$, large differences can be seen in sector emissions. For the CORP inventory, no sector information is available. CO emissions range from $10 \mathrm{Tg}$ (CORP) to $116 \mathrm{Tg}$ (TRACE-P). EDGAR and TRACE-P emissions differ by $30 \%$ while the CORP values seem unrealistically low. Again, EDGAR and TRACE-P show large sector differences. For example, transport emissions in EDGAR are 1/3 of the TRACE-P estimate while domestic emissions in EDGAR are twice the TRACE-P value. NMVOC emissions range from $11 \mathrm{Tg}$ (EDGAR) to $25 \mathrm{Tg}$ (CORP) with $45 \%$ difference between TRACE-P and the other inventories. Emissions by sector between EDGAR and TRACE-P show large differences, except for domestic emissions.

The distribution of emissions (Fig. 1) shows a common feature between the inventories with low emissions in western China and high emissions in the east. In contrast with
TRACE-P and CORP, EDGAR assigns zero emissions to western China (Tibetan Plateau). The distribution of $\mathrm{NO}_{\mathrm{x}}$ emissions show higher peak values by EDGAR and CORP with more equal distribution values of TRACE-P. For example, the Shanghai region shows value $>300 \mathrm{Gg}$ per year in EDGAR and CORP while TRACE-P shows values of 100$200 \mathrm{Gg}$ per year. For CO emissions, CORP shows very low CO values (100-200 Gg in eastern China) in comparison with the $>200 \mathrm{Gg}$ values in EDGAR and TRACE-P inventories. As with the $\mathrm{NO}_{\mathrm{x}}$ emissions, the distribution of NMVOC emissions show higher values in the CORP inventory $(200-300 \mathrm{Gg})$ in comparison with the more equally distributed emissions within the EDGAR and TRACE-P inventories.

As shown above significant differences are observed between the three emission inventories. Based on the available information it cannot be assessed which inventory provides the most accurate emission estimate for the year 1995. In general the following can be stated: 
- EDGAR: emission estimates at higher aggregation levels than the other inventories (both budget and grid). However, calculations are representative for the year 1995 and based on international datasets.

- TRACE-P: rather detailed emission inventory, which has used detailed geographical maps to distribute the emissions. However, emissions are not representative for the year 1995 .

- CORP: emission calculations at detailed prefecture level in China (budget and grid). Emissions are representative for the year 1995 and emission factors based on local measurements have been used. However, documentation of the inventory is insufficient.

\section{Regional ozone modelling}

The model used in this study is a 3-D regional chemical transport model (Ma et al., 2002a), which is extended from the Regional Acid Deposition Model (RADM) and aimed at studying the distribution and budget of tropospheric ozone and its precursors over China. The model domain covers China with a horizontal resolution of $100 \mathrm{~km}$. In the vertical, the model extends up to pressure levels of 10 mbar for meteorological simulations and to the local thermal tropopause for chemical integration. The meteorological fields for the model run are provided with the Fifth-Generation NCAR/Penn State Mesoscale Model (MM5). The chemical gas-phase mechanism in the model was initially developed by Stockwell (1986), and modified by updating the rate constants, introducing the effective photodissociation of ozone, incorporating the permutation reactions of organic peroxy radicals, and replacing the lumped $\mathrm{NO}_{3}+\mathrm{N}_{2} \mathrm{O}_{5}$ reaction rate expressions with the explicit ones (Ma et al., 2000). The revised chemical mechanism was well compared with the explicit NCAR's Master Mechanism using the trace gas concentrations observed at the China regional background atmospheric observatory as model initial conditions. The mechanism was further improved by adding acetone as a tracer into the model and including parameterization of heterogeneous reactions of $\mathrm{N}_{2} \mathrm{O}_{5}$ and $\mathrm{NO}_{3}$ on sulfate aerosols (Ma et al., 2002a). The model implemented with this mechanism was used for the study of tropospheric ozone over China by Ma et al. (2002a, b). In addition to updated anthropogenic surface emissions, natural NMVOC emissions, aircraft emissions and lightning $\mathrm{NO}_{\mathrm{x}}$ sources are taken into account. The initial fields and lateral boundary condition for most chemical traces are provided with a global chemical transport model for ozone and related chemical tracers (MOZART).

The three emission inventories have been implemented into the model followed by a sensitivity run for each inventory. The model simulation is performed for a summertime period, 1-15 July 1995 over which the results are averaged and analyzed. While different emission inventories are used for China, the EDGAR inventory was applied for other countries in the model domain in all simulations. Since all other model settings are kept constant, the difference in simulated ozone will be due to various independent emission inventories for China. The model sensitivity has been tested for (i) ozone precursor concentrations, (ii) net ozone production, (iii) ozone concentrations, (iv) validation of the model using Global Atmospheric Watch (GAW) measurements and (v) exceedance of ozone standards.

\subsection{Ozone precursor concentrations}

Figure 2 presents the difference in calculated $\mathrm{NO}_{\mathrm{x}}, \mathrm{CO}$ and $\mathrm{CH}_{2} \mathrm{O}$ for the three model simulations. For illustrative purposes, the model results using the EDGAR emission estimates for China are shown as a base case (Fig. 2a). The model results using TRACE-P (case C1) and CORP (case $\mathrm{C} 2$ ) are presented as deviations from this reference case (case B). Selection of the EDGAR emission inventory as references is arbitrarily based on the fact that it is widely used in atmospheric modelling. It does however not imply that it is better than the other inventories.

In much of the troposphere, ozone production is limited by the abundance of $\mathrm{NO}_{\mathrm{x}}$ (WMO, 1995). In China, most $\mathrm{NO}_{\mathrm{x}}$ emissions are confined in the boundary layer near the surface (Ma et al., 2002a), which are mainly from fossil fuel combustion. Figure 2a1 presents surface $\mathrm{NO}_{\mathrm{x}}$ concentrations calculated using EDGAR. Due to the short lifetime, high $\mathrm{NO}_{x}$ concentrations are found in areas with large $\mathrm{NO}_{\mathrm{x}}$ emissions. High $\mathrm{NO}_{\mathrm{x}}$ concentrations of 3-9 ppbv are found in the eastern and middle part of China. Low $\mathrm{NO}_{\mathrm{x}}$ concentrations are found in the western China, notably around the Tibetan Plateau. Peak values of $\mathrm{NO}_{\mathrm{x}}(>9 \mathrm{ppbv})$ can be seen around the Chengdu, Shanghai and Beijing areas.

The relative differences between the reference case and the calculations using TRACE-P and CORP are shown in Figs. $2 \mathrm{~b} 1$ and c1, respectively. Large differences in $\mathrm{NO}_{\mathrm{x}}$ concentrations will be found in areas where emissions are different (see Fig. 1). These differences are visible in North China (including Beijing and Shijiazhuang), Northeast China (including Shengyuang and Haerbin) as well as in the Sichuan Basin (including Chengdu and Chongqing) and East China regions (including Shanghai and Nanjing). Both TRACE-P and CORP simulations show up to $200 \%$ higher $\mathrm{NO}_{\mathrm{x}}$ concentrations in the low emission areas in the western and northern parts of China. These differences appear to be larger in western China for TRACE-P, while the CORP simulation results in large difference with EDGAR in Northeast China. In the areas in Central and Eastern China with large emissions, the EDGAR simulation results in $20-100 \%$ higher $\mathrm{NO}_{\mathrm{x}}$ concentrations than TRACE-P and CORP. The difference can be around $3 \mathrm{ppbv}$ or higher which is comparable to the $\mathrm{NO}_{\mathrm{x}}$ levels in the polluted rural areas of East Asia (WMO, 1995).

The primary source of $\mathrm{CO}$ is estimated to come predominantly from anthropogenic origin. In addition, the oxidation 

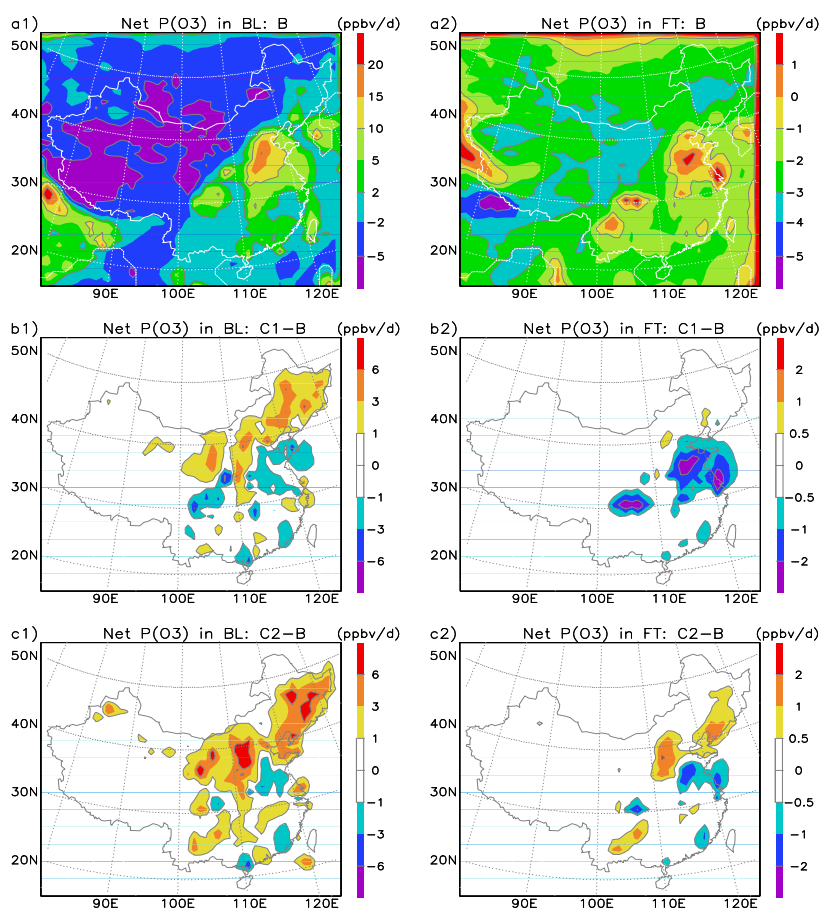

Fig. 3. Differences in calculated net production of ozone, $\mathrm{P}\left(\mathrm{O}_{3}\right)$, for the boundary layer (BL) and the free troposphere (FT) due to the use of different emission inventories EDGAR, TRACE-P and CORP (denoted as cases B, C1 and C2, respectively). Simulated results with EDGAR are given as reference and the differences are shown with the deviations of TRACE-P and CORP to EDGAR.

of $\mathrm{CH}_{4}$ and NMVOC provide an important secondary source of CO in the atmosphere (Von Kuhlmann, 2001). In the EDGAR simulation (Fig. 2a2) higher CO concentrations (>400 ppbv) are found in eastern China and lower concentrations in the west. Peak CO concentrations (700-900 ppbv) are found in the Chengdu area of the Sichuan Basin, a larger area of North China below Beijing and a small area of East China near Shanghai. While CO concentrations from the TRACE-P simulation are comparable with EDGAR (Fig. 2b2), CO concentrations from the CORP simulation show values of up to $100 \%$ lower in eastern China.

Since NMVOC includes many species that are involved in the oxidation reactions for ozone formation (Atkinson, 2000), lumped NMVOC species are used for the purpose of simplification and efficient calculation of the model (Ma et al., 2002a). Therefore, it is not convenient to compare the results with observations or other model studies if the concentrations of total NMVOC are presented. Propeneequivalent NMVOC was used to analyze the relationship between ozone and its precursors in Chameides et al. (1992). In this paper distribution of $\mathrm{CH}_{2} \mathrm{O}$ are shown. As shown in Fig. 2a3, $\mathrm{CH}_{2} \mathrm{O}$ concentrations follow the pattern of $\mathrm{NO}_{\mathrm{x}}$ and $\mathrm{CO}$ concentrations (Figs. 2a1, a2). In the regions with high emissions the EDGAR and TRACE-P simulations (Fig. 2b3) show comparable concentrations. In low emission areas, the results from TRACE-P show larger $\mathrm{CH}_{2} \mathrm{O}$ concentrations. The difference between the EDGAR and CORP simulations is rather large. The CORP simulations show differences larger 200\% in North and Northeast China.

\subsection{Net ozone production}

Figure 3a shows the net ozone production for the boundary layer (Fig. 3a1) and free troposphere (Fig. 3a2) as calculated in the EDGAR simulation. The largest net ozone production values are found in the polluted regions of eastern China, with maximum values of 10-15 ppbv/day. Figures $3 \mathrm{~b}$ and $\mathrm{c}$ show the differences between the EDGAR and the TRACE$\mathrm{P}$ and CORP simulations. In general, the CORP simulation results in higher net ozone production in the boundary layer, especially in North and Northeast China. The largest differences are up to $6 \mathrm{ppbv/day,} \mathrm{which} \mathrm{is} \mathrm{nearly} 30-50 \%$ of maximum net ozone production estimated for the polluted regions of eastern China (Mauzerall et al., 2000; Ma et al., 2002a). The EDGAR and TRACE-P simulations differ with higher net ozone production in Northeast China for TRACE-P and with higher values using EDGAR for the Sichuan Basin and East China regions. This difference is relatively small in comparison to the CORP simulation. In the free troposphere (Figs. 3a2, b2, c2) the difference in net ozone production is confined to limited regions, but its magnitude is still considerable, reaching to $1 \mathrm{ppbv/day}$ or more in some regions.

\subsection{Ozone concentrations}

Figure 4 presents simulated $\mathrm{O}_{3}$ concentrations at the surface (4a1) and at 500 mbar height (4a2) using the EDGAR inventory together with differences with the TRACEP (4b1, b2) and CORP $(4 \mathrm{c} 1, \mathrm{c} 2)$ simulations. High $\mathrm{O}_{3}$ concentrations are found in Central east and Northeast China and on the Tibetan plateau where altitudes fall in the middle troposphere. For surface ozone, the differences occur mainly in Northeast China and the East China Sea. Both the CORP and TRACE$\mathrm{P}$ simulations result in ozone concentrations with the difference reaching up to $50 \%$ at some locations (e.g. Shanghai area) but in general the differences are less than 30\%. Differences in ozone concentration at 500 mbar show a different pattern. Here the differences occur over the Sichuan Basin, East China and its down-stream regions over the sea. This corresponds to the corridor where $\mathrm{O}_{3}$ is predominantly attributed to photochemistry (Ma et al., 2002b). The EDGAR simulations show slightly higher values (up to 5\%) than the TRACE-P simulation. Results from CORP and EDGAR are comparable, except for the Guizhou area with up to $3 \%$ higher concentrations in the CORP simulation.

The reasons for the smaller difference in simulated ozone concentration than in its precursors, for instance, $\mathrm{NO}_{\mathrm{x}}$, are complicated. In unpolluted areas (e.g. western China), anthropogenic $\mathrm{NO}_{\mathrm{x}}$ emissions as well as its concentrations are 

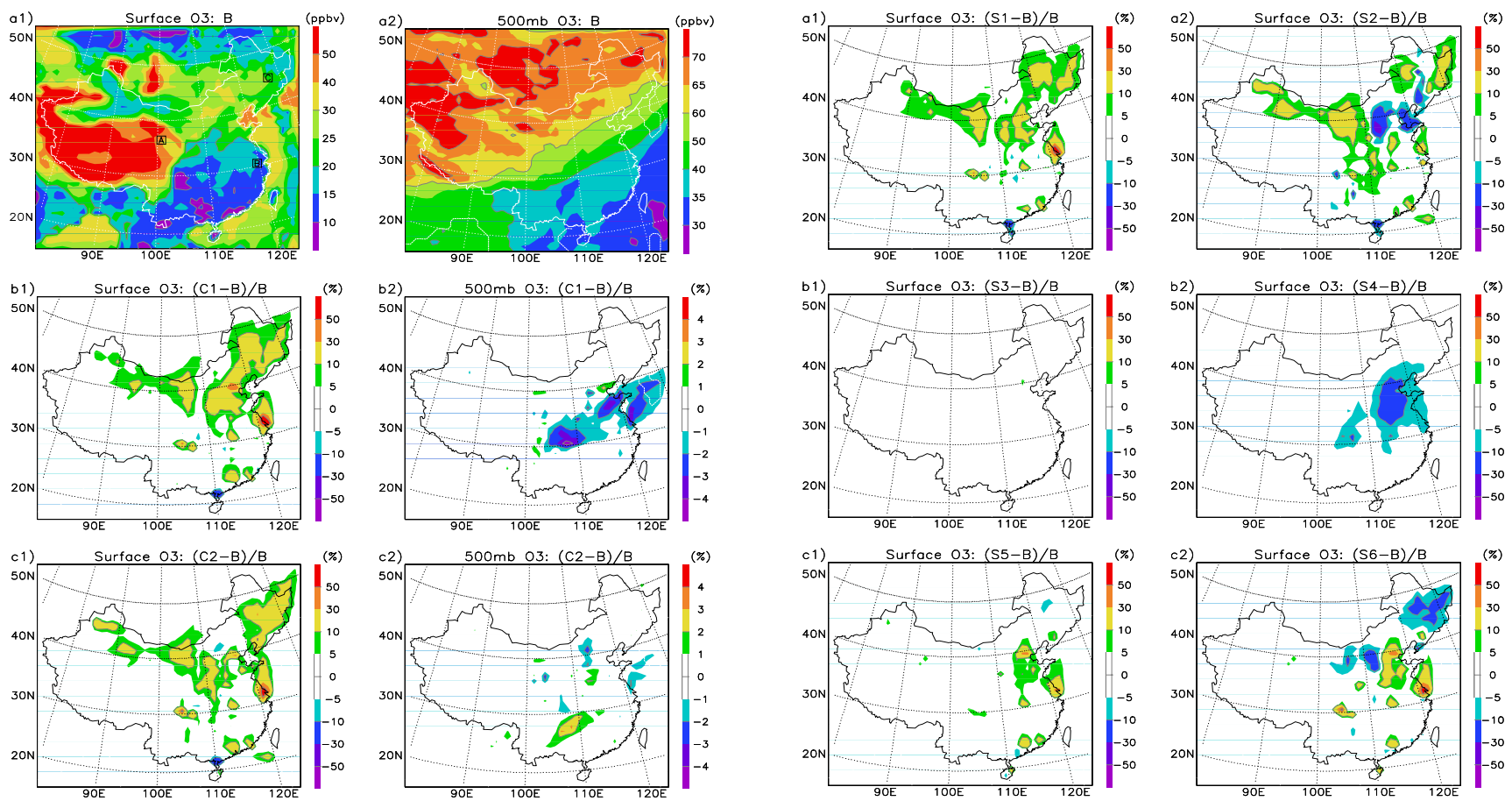

Fig. 4. Differences in simulated $\mathrm{O}_{3}$ at the surface and $500 \mathrm{mbar}$ height due to the use of different emission inventories EDGAR, TRACE-P and CORP (denoted as cases B, C1 and C2, respectively). Simulated results with EDGAR are given as reference and the differences are shown with the deviations of TRACE-P and CORP to EDGAR.

low, and ozone is controlled mainly by the transport (Ma et al., 2002b). The differences in $\mathrm{NO}_{\mathrm{x}}$ emissions as well as its concentrations may be rather larger in relative sense. However, the differences in simulated ozone concentrations are smaller due to rather small fraction of ozone attributed to in situ photochemistry. In polluted areas (e.g. most parts of eastern China), anthropogenic $\mathrm{NO}_{\mathrm{x}}$ emissions as well as its concentrations are high, and ozone is controlled mainly by photochemistry (Ma et al., 2002b). Ozone concentrations should be sensitive to the variations in $\mathrm{NO}_{\mathrm{x}}$ concentrations and thus its emissions. However, the amount of ozone produced per $\mathrm{NO}_{\mathrm{x}}$ emitted is not linear (Liu et al., 1987; Lin et al, 1988; Trainer et al., 1993). With $\mathrm{NO}_{\mathrm{x}}$ ozone production increases at high $\mathrm{NO}_{\mathrm{x}}$ levels and decreases at high $\mathrm{NO}_{\mathrm{x}}$ levels, and the $\mathrm{NO}_{\mathrm{x}}$ threshold is around 1-10 ppbv, depending on NMVOC conditions and so on (Poppe et al., 1998). Generally, surface $\mathrm{NO}_{\mathrm{x}}$ levels in polluted areas of eastern China fall in this range (Fig. 2a1). Therefore, the differences in simulated ozone vary and can be opposite in sign with the differences in simulated $\mathrm{NO}_{\mathrm{x}}$ (Figs. 2b1, 3b1 and 4b1). Kasibhatla et al. (1998) estimated that the net ozone production efficiency (OPE) ranges from 2 to 3 ppbv $\mathrm{O}_{3} \mathrm{ppbv}^{-1} \mathrm{NO}_{\mathrm{x}}$ in the eastern United States during summer. Assuming a $100 \%$ $\mathrm{NO}_{\mathrm{x}}$ increase at 3 ppbv $\mathrm{NO}_{\mathrm{x}}$ and $30 \mathrm{ppbv} \mathrm{O}_{3}$, the $\mathrm{O}_{3}$ increase

Fig. 5. Differences in simulated surface $\mathrm{O}_{3}$ due to the use of different emission rates of EDGAR, TRACE-P and CORP for a specific species while keeping rest the same as those of EDGAR. The simulated result with EDGAR is taken as reference, which is given in Fig. 4a1. The differences are shown with the relative deviations to EDGAR when TRACE-P $\mathrm{NO}_{\mathrm{X}}, \mathrm{CO}$ and NMVOC (denoted as $\mathrm{S} 1$, $\mathrm{S} 3$ and $\mathrm{S} 5$ ) and CORP $\mathrm{NO}_{\mathrm{x}}, \mathrm{CO}$ and NMVOC (denoted as S2, S4 and S6) are used, respectively.

is estimated to be 6 to 9 ppbv, i.e. $20-30 \%$ increase in relative sense. Our results are in agreement with this estimate, indicating that the model chemical mechanism we used is reliable.

To determine whether it is the combination of different emission estimates or the difference in one species that controls the difference in ozone concentrations, additional model simulations were performed which are discussed here briefly. The model sensitivity runs were performed with the scenarios below, where EDGAR emissions were replaced with TRACE-P or CORP for one species.

S1: TRACE-P $\mathrm{NO}_{\mathrm{x}}$ with EDGAR CO and NMVOC; S2: CORP $\mathrm{NO}_{\mathrm{x}}$ with EDGAR $\mathrm{CO}$ and NMVOC; S3: TRACE-P CO with EDGAR $\mathrm{NO}_{\mathrm{x}}$ and NMVOC; S4: CORP CO with EDGAR $\mathrm{NO}_{\mathrm{x}}$ and NMVOC; S5: TRACE-P NMVOC with EDGAR $\mathrm{NO}_{\mathrm{x}}$ and CO; S6: CORP NMVOC with EDGAR $\mathrm{NO}_{\mathrm{x}}$ and CO.

Differences in simulated surface $\mathrm{O}_{3}$ due to the use of these scenarios are compared with the reference simulation using the EDGAR emission inventory for all species. 

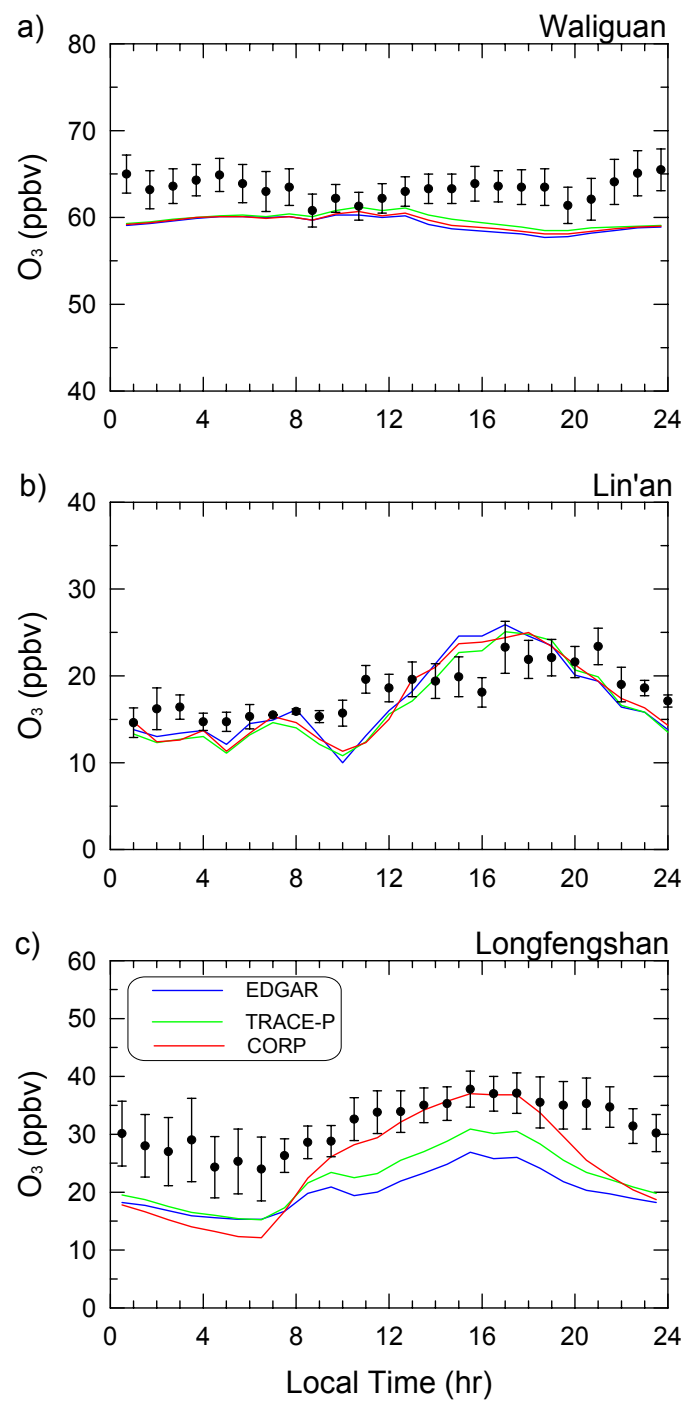

Fig. 6. Simulated mean diurnal cycles of surface $\mathrm{O}_{3}$ at the three WMO/GAW background stations Mt. Waliguan, Lin'an and Longfengshan for different emission inventories EDGAR, TRACE$\mathrm{P}$ and CORP (denoted as blue, green and red lines, respectively). Observations (circles, with bars for standard deviations) are also shown for comparison. The geographic position of the stations is given in Fig. 4a1 and denoted by A, B and C for Mt. Waliguan, Lin' an and Longfengshan, respectively.

As shown in Fig. 5a1, the difference between EDGAR and TRACE-P (Fig. 4a1) is caused dominantly by the difference in $\mathrm{NO}_{\mathrm{x}}$ emissions, in addition, partly by the difference in NMVOC emissions (Fig. 5c1). The difference in the CO emission between EDGAR and TRACE-P has little effect on simulated surface $\mathrm{O}_{3}$ (Fig. 5b1). The difference between CORP and EDGAR (Fig. 4c1) is caused by the combined effect of difference in the emission of $\mathrm{NO}_{\mathrm{x}}$ (Fig. 5a2), $\mathrm{CO}$ (Fig. 5b2) and NMVOC (Fig. 5c2). This effect, however, is not a simple addition of the emission differences but is an effect of the non-linear characteristics of ozone chemistry.

\subsection{Diurnal variation of ozone at GAW stations}

Measurements of ozone and its precursors are sparse in China, especially in the rural areas. Surface ozone was observed at the three WMO Global Atmosphere Watch (GAW) background stations in the CORP programme (Zhou, 1996). Figure 6 presents the simulated mean diurnal cycles of $\mathrm{O}_{3}$ at stations Mt. Waliguan (WLG), Lin'an (LA) and Longfengshan (LFS). The location of these stations is shown in Fig. 4a1 with markings A (WLG), B (LA) and C (LFS). Simulated daily variations of $\mathrm{O}_{3}$ at the WLG and LA stations do not show large difference between the three simulations. The differences between the simulations and observation are relatively small with a good fit at LA and with some underestimation at WLG station.

As can be expected, simulated $\mathrm{O}_{3}$ at WLG stations is nearly the same for all three simulations. The source of $\mathrm{O}_{3}$ at WLG is mainly from long-range transport outside China (Ma et al., 2002b). The sources of $\mathrm{O}_{3}$ at LA are both from photochemistry inside and transport outside China (Ma et al., 2002b). The close agreement between the simulation at LA are due to the small differences in emission estimates for the rural areas of south China and dominating sea winds. Simulated daily $\mathrm{O}_{3}$ variations at LFS stations show different results. While the CORP simulation reproduces observed $\mathrm{O}_{3}$ during the day, there is an underestimation for both EDGAR and TRACE-P calculations. Because LFS is in the summer downstream of polluted areas, the emission inventory differences in Northeast and North China might contribute to the differences found at this station.

\subsection{Exceedance of ozone standards in selected grid cells}

As shown in Fig. 4, differences in simulated surface $\mathrm{O}_{3}$ are large in North and Northeast China. This could have implications for studying ozone exceedance in major cities in that area. Figure 7 presents the hourly $\mathrm{O}_{3}$ variation in selected model grid cells where six large cities in North and Northeast China are located. The government of China has set several ozone standards of which the first level standard of $60 \mathrm{ppbv}$ hourly maximum has been applied. Although the size of model grid cell is not small enough to resolve a city, the simulated results can be an indicator of air quality al least for the regions where these cities are. As shown in Fig. 7, several cities show an exceedance of this standard, especially in the first days of the simulation period. For the city of Beijing and Tianjin, it is clearly visible that the EDGAR simulation does not lead to exceedance of the ozone standard while the TRACE-P and CORP simulations result in exceedance during several days. The maximum difference in hourly-averaged ozone concentration can reach up to $40 \mathrm{ppbv}$ or $100 \%$ in relative sense. For the other cities, ozone concentrations rarely exceed the standard, but the relative deviation due to different emission inventories is still high sometimes with a maximum of near $100 \%$. 


\section{Conclusions}

In this paper the sensitivity of simulated ozone to different emission inventories of ozone precursors has been studied. Three independent emission inventories (EDGAR, TRACE$\mathrm{P}$ and CORP) with emission estimates for $\mathrm{NO}_{\mathrm{x}}, \mathrm{NMVOC}$ and $\mathrm{CO}$ in China have been used as input for simulations with a regional chemical transport model (Ma et al., 2002a).

Large differences were found in the simulated precursor concentrations. For both $\mathrm{NO}_{\mathrm{x}}$ and NMVOC the EDGAR calculations resulted in lower concentrations in the northern part of China. For $\mathrm{NO}_{\mathrm{x}}$ these differences are up to $200 \%$ while for NMVOC these differences are up to $100 \%$ in comparison with TRACE-P and up to $200 \%$ with CORP. Simulation of CO concentrations using EDGAR and TRACE-P are comparable with differences of about $20 \%$. The CORP simulation results in significant lower CO concentrations (up to 100\%) than the other simulations. These differences are most likely caused by the different $\mathrm{CO}$ emission budgets with CORP estimating 5-6 lower $\mathrm{CO}$ emissions than the other two inventories.

Although large differences were found in the precursor concentrations and significant differences occurred in the boundary layer net ozone production values, the differences in ozone concentrations are relatively small for a regional ozone model. Differences in surface ozone occurred mainly in North and Northeast China with as well as in the East China Sea. Both CORP and TRACE-P simulations showed higher ozone concentrations than the EDGAR simulations with differences of up to $50 \%$ in the Shanghai and Beijing area. For most of the model domain, however, differences are only $5-30 \%$. Differences in $\mathrm{O}_{3}$ at 500 mbar occur mainly over the Sichuan Basin, North China and its down-stream regions over the sea, with maximum differences of 1-2 ppbv (less than 5\%). Application of TRACE-P generally resulted in lower $\mathrm{O}_{3}$ values at 500 mbar in comparison with EDGAR and CORP.

The results from additional local simulations in which one species from the TRACE-P and CORP emission inventory was mixed with the EDGAR estimates for the other species showed that the difference between TRACE-P and the EDGAR simulations can be attributed mainly to the $\mathrm{NO}_{\mathrm{x}}$ emission inventory differences, less to NMVOC and not to $\mathrm{CO}$ emission inventory differences. Given the discussion above on precursor concentrations, the difference in ozone calculations between EDGAR and TRACE-P are mainly related to the difference in distribution of the $\mathrm{NO}_{\mathrm{x}}$ emissions. The differences between EDGAR and CORP ozone calculations is less clear and seems to be the combined effect of differences in $\mathrm{NO}_{\mathrm{x}}, \mathrm{CO}$ and $\mathrm{NMVOC}$ emissions.

The main purpose of this paper is to discuss to what extent uncertainty in regional emission inventories really matters for the outcome of atmospheric modelling studies.

As far as surface $\mathrm{O}_{3}$ in rather unpolluted areas and $\mathrm{O}_{3}$ at higher altitudes (500 mbar) are concerned, the different sim-

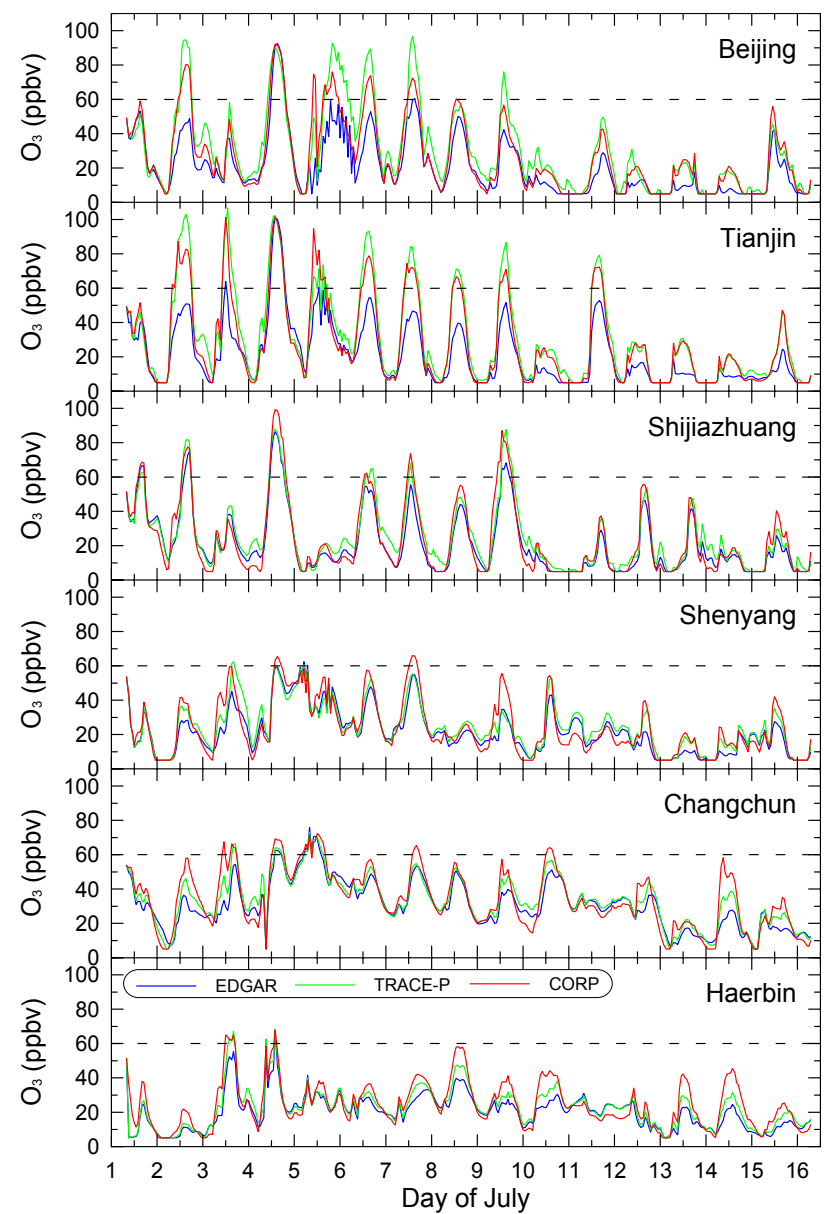

Fig. 7. Simulated hourly variations of surface $\mathrm{O}_{3}$ for the selected model grid cells with different emission inventories EDGAR, TRACE-P and CORP (denoted as blue, green and red lines, respectively). The grid cells are denoted with the name of big cities which are included in the grid cells. The first-level ozone standard (60 ppbv) is shown with black dashed lines.

ulations show that the application of different emission inventories did not result in significant differences. For the higher altitudes, photochemistry and atmospheric transport play a more important role than the variation (uncertainty) in surface emissions. For the unpolluted areas, the relative differences in the emission inventories were found to be large but due to the low emissions values this does not have a large effect on simulated ozone values.

As far as surface $\mathrm{O}_{3}$ in polluted areas is concerned, the results show that $30-50 \%$ differences in ozone concentrations values were found. Maximum differences of $10 \mathrm{ppbv}$ were found in the region where the big cities of Beijing and Tianjin are located. Although the inventories show large differences, regional modelling of ozone shows concentrations within 30-50\% which - at first sight - does not seem very large for this type of modelling, especially when the emission inventories show large differences. 
For more localized studies, for which the model suitability could be questioned, significant differences were observed. In the area where maximum differences (10 ppbv) were found, ozone levels in Beijing and Tianjin were above the exceedance level in the TRACE-P and CORP calculations while the EDGAR calculations did not lead to exceedance. In this case the difference in emission inventories did matter. In addition, the comparison of the diurnal $\mathrm{O}_{3}$ cycles with the measurements made at a WMO/GAW regional background station, the Longfengshan station, was dependent on which emission inventory was used for the model calculation.

In the opinion of the authors, a difference of $30-50 \%$ in simulated ozone values, between model calculations using either a (i) inventory of high aggregation level with several global default emission factors, (ii) detailed inventory with emissions not representative for 1995 and (iii) detailed inventory of $\mathrm{NO}_{\mathrm{x}}$ emissions with unknown method for $\mathrm{CO}$ and a scaling of $\mathrm{NO}_{\mathrm{x}}$ emissions to reach NMVOC estimates, is not extremely large. In this perspective the uncertainty in emission inventories does not lead to important different insights and the strain on emission inventories being the limitation in regional ozone modelling seems to be unjustified, especially when meteorological variations or chemical reactions within the model could also lead to large variation in the model outcome.

Finally, a question to be answered is which inventory should be used for simulating summertime ozone in China in 1995? If the measurements at the Longfenshang station in Northeast China are used as an indicator, one should have more confidence in the CORP emission inventory than in the EDGAR and TRACE-P emission inventories. However, given its large underestimation of $\mathrm{CO}$ emission values this confidence seems to be misplaced. In general, there is no confidence to highlight which emission inventory is better than the other at the present time. Either a detailed comparison of methodology of the three emission inventories or the availability of more measurements to validate the model result could provide this insight. Unfortunately, this is not possible due to lack of documentation on the CORP inventory and the limited amount of measurement data.

Acknowledgements. The authors would like to thank M. Lawrence and J. Lelieveld for their comments and suggestions on this work. J. Ma also acknowledges the support of MOST under the project 2002DIA20012. Special thanks go to the START Visiting Scientist Programme for supporting J. Ma's visit to the Max Planck Institute for Chemistry.

Edited by: A. Guenther

\section{References}

Andreae, M. O. and Merlet, P.: Emissions of trace gases and aerosols from biomass burning, Global Biogeochemical Cycles, 15, 955-966, 2001.
Atkinson, R.: Atmospheric chemistry of VOCs and NOx, Atmospheric Environment, 34, 2063-2101, 2000.

Bai, N. B.: The emission inventory of $\mathrm{CO}_{2}, \mathrm{SO}_{2}$, and $\mathrm{NO}_{\mathrm{x}}$ in China, in The Atmospheric Ozone Variation and Its Effect on the Climate and Environment in China, edited by Zhou, X. J., 145-150, Meteorological Press, Beijing (in Chinese), 1996.

Berntsen, T., Isaksen, I. S. A., Wang, W.-C., and Liang, X.-Z.: Impacts of increased anthropogenic emissions in Asia on tropospheric ozone and climate: A global 3-D model study, Tellus, 48B, 13-32, 1996.

Chameides, W. L, Fehsenfeld, F., Rodgers, M. O., Cardelino, C., Martinez, J., Parrish, D., Lonneman, W., Lawson, D., Rasmussen, R., Zimmerman, P., Greenberg, J., and Middleton, P. Ozone precursor relationships in the ambient atmosphere, J. Geophys. Res., 97 (D5), 6037-6055, 1992.

Fu, L., Hao., J., He, D., He, K., and Li, P.: Assessment of vehicular pollution in China, Journal of Air and Waste Management Association, 51, 658-668, 2001.

IEA/OECD: Beyond 20/20, Release 4.1, Energy balances of OECD countries, Energy balances of Non-OECD countries, Ivation DatasystemsInc, 1997.

Kasibhatla, P., Chameides, W. L., Saylor, R. D., and Olerud, D.: Relationships between regional ozone pollution and emissions of nitrogen oxides in the eastern United States, J. Geophys. Res., 103, 22 663-22 669, 1998.

Lin, X., Trainer, M., and Liu, S.: On the nonlinearity of tropospheric ozone production, J. Geophys. Res., 93, 15 879-15 888, 1988.

Liu, S., Fehsenfeld, F., Parrish, D. D., Williams, E., Fahey, D. W., Huebler, G., and Murphy, P.: Ozone production in the rural troposphere and the implications for regional and global distributions, J. Geophys. Res., 92, 4191-4207, 1987.

Ma, J., Li, W. L., and Zhou, X. J.: Improvements of RADM1 gas phase chemical mechanism, J. Environ. Sci. Health, A35, 19311939, 2000.

Ma, J., Liu, H., and Hauglustaine, D.: Summertime tropospheric ozone over China simulated with a regional chemical transport model, Part 1. Model description and evaluation, J. Geophys. Res., 107 (D22), 4660, doi:10.1029/2001JD001354, 2002a.

Ma, J., Zhou, X., and Hauglustaine, D.: Summertime tropospheric ozone over China simulated with a regional chemical transport model, Part 2. Source contribution and budget, J. Geophys. Res., 107 (D22), 4612, doi:10.1029/2001JD001355, 2002b.

Mauzerall, D. L., Narita, D., Akimoto, H., Horowitz, L., Walters, S., Hauglustaine, D. A., and Brasseur, G.: Seasonal characteristics of tropospheric ozone production and mixing ratios over East Asia: A global three-dimensional chemical transport model analysis, J. Geophys. Res., 105, 17 895-17 910, 2000.

Olivier, J., Bouwman, A. F., Van der Maas, C. W. M., Berdowski, J. J. M., Veldt, C., Bloos, J. P. J., Visschedijk, A. J. H., Zandveld, P. Y. J., and Haverlag, J. L.: Description of EDGAR Version 2.0: A set of emission inventories of greenhouse gases and ozone depleting substances for all anthropogenic and most natural sources on a per country basis and on $1^{\circ} \times 1^{\circ}$ grid, RIVM Rep. 771060002, Bilthoven: National Institute of Public Health and the Environment, 1996.

Olivier, J. G. J., Bloos, J. P. J., Berdowski, J. J. M., Visschedijk, A. J. H., and Bouwman, A. F.: A 1990 global emission inventory of anthropogenic sources of carbon monoxide on $1^{\circ} \times 1^{\circ}$ devel- 
oped in the framework of EDGAR/GEIA, Chemosphere: Global Change Science, 1, 1-17, 1999.

Olivier, J. G. J, Peters, J. A. H. W., Bakker, J., Berdowski, J. J. M., Visschedijk, A. J. H., and Bloos, J. P. J.: Applications of EDGAR: emission database for global atmospheric research, Report no.: 410.200.051. RIVM, The Netherlands, 2002.

Pacyna, J. M. and Graedel, T. E.: Atmospheric emission inventories: status and prospects, Annual review of energy and the environment, 20, 265-300, 1995.

Poppe, D., Koppmann, R., and Rudolph, J: Ozone formation in biomass buning plumes: Influence of atmospheric dilution, Geophys. Res. Lett., 25, 3823-3826, 1998.

Russell, A. and Dennis, R.: NARSTO critical review of photochemical models and modelling, Atmos. Environ., 34, 2283-2324, 2000.

Sintion, J. E. and Fridley, D. G.: What goes up: recent trends in China's energy consumption, Energy and Policy, 28, 671-687, 2000.

Stockwell, W. R.: A homogeneous gas-phase mechanism for use in a regional acid deposition model, Atmos. Environ., 20, 16151632, 1986.

Streets, D. G., Bond, T. C., Carmichael, G. R., Fernandes, S. D., Fu, Q., He, D., Klimont, Z., Nelson, S. M., Tsai, N. Y., Wang, M. Q., Woo, J.-H., and Yarber, K. F.: An inventory of gaseous and primary aerosol emissions in Asia in the year 2000, J. Geophys. Res., 108 (D21), 8809, doi:10.1029/2202JD003093, 2003.
Trainer, M., Parrish, D. D., Buhr, M. P., Norton, R. B., Fehsenfeld, F. C., Anlauf, K. G., Bottenheim, J. W., Tang, Y. Z., Wiebe, H. A., Roberts, J. M., Tanner, R. L., Newman, L., Bowersox, V. C., Meagher, J. F., Olszyna, K. J., Rodgers, M. O., Wang, T., Berresheim, H., Demerjian, K. L., and Roychowdhury, U. K.: Correlation of ozone with NOy in photochemically aged air, J. Geophys. Res., 98, 2917-2925, 1993.

United Nations (UN): Industrial commodity production statistics 1970-1995. UN Statistical Division, New York, Data file received 30-1-1998.

Van Aardenne, J. A., Carmichael, G. R., Levy, H., Streets, D., and Hordijk, L.: Anthropogenic $\mathrm{NO}_{\mathrm{x}}$ emissions in Asia in the period 1990-2020, Atmos. Environ., 33, 633-646, 1999.

Von Kuhlmann, R.: Tropospheric photochemistry of ozone, its precursors and hydroxyl radical: A 3-D modeling study considering non-methane hydrocarbons, Ph.D thesis, University of Mainz, Mainz, Germany, 2001.

World Meteorological Organization (WMO): Scientific Assessment of Ozone Depletion: 1994, Global Ozone Research and Monitoring Project, Rep. 37, Geneva, Switzerland, 1995.

Zhou, X. J. (Ed.): The Atmospheric Ozone Variation and Its Effect on the Climate and Environment in China, Meteorological Press, Beijing (in Chinese), 1996. 